\title{
AGRONOMIC POTENTIAL AND GENETIC DIVERSITY OF LANDRACES OF COWPEA OF THE STATE OF CEARÁ ${ }^{1}$
}

\author{
LINDA BRENNA RIBEIRO ARAÚJO2*, MARCELO DE SOUSA PINHEIRO ${ }^{2}$, LEONARDO BARROS DA COSTA \\ FIEGE $^{2}$, CÂNDIDA HERMÍNIA CAMPOS DE MAGALHÃES BERTINI ${ }^{2}$, JÚLIO CÉSAR DOVALE ${ }^{2}$
}

\begin{abstract}
Landraces are sources of genetic variability, especially with respect to alleles that confer tolerance to biotic and abiotic factors and, therefore, can aid breeding programs in the development of promising cultivars. However, it is necessary to know this genetic patrimony at a level that allows its alleged use in breeding programs. In this sense, the objective of this study was: (i) to identify cowpea landraces that present agronomic potential and (ii) to evaluate the genetic diversity for future cross-breeding. For this, two trials (coastal and sertão of the state of Ceará) were carried out in distinct periods for the morphological and agronomic characterization of eight landraces of the state of Ceará plus two control cultivars. Both assays were conducted in a randomized complete block design with four replicates. Additionally, the molecular characterization by ISSR markers was done. Due to the presence of interaction genotypes by environments, it was observed for the conditions of the coast (Fortaleza), the traditional variety Boi Deitado and the conditions of the sertão (Madalena) to Vinagre Barrigudo de Caldo, as the most indicated to be superior in grain yield and in other agronomic characters. In order to increase the genetic base of the cowpea, we suggest crosses between genotypes Boi deitado and Cojó for the generation of segregating populations of future breeding programs.
\end{abstract}

Keywords: Vigna unguiculata. Genetic resources. Morphoagronomic characterization. ISSR markers.

\section{POTENCIAL AGRONÔMICO E DIVERSIDADE GENÉTICA DE VARIEDADES TRADICIONAIS DE FEIJÃO-CAUPI DO ESTADO DO CEARÁ}

\begin{abstract}
RESUMO - Variedades tradicionais são fontes de variabilidade genética, principalmente no que se refere a alelos que conferem tolerância a fatores bióticos e abióticos e, portanto, podem auxiliar os programas de melhoramento no desenvolvimento de cultivares promissoras. Contudo, torna-se necessário conhecer esse patrimônio genético em nível que permita sua pretensa utilização em programas de melhoramento genético. Assim, objetivou-se com esse estudo: (i) identificar variedades tradicionais de feijão-caupi que apresentem potencial agronômico e (ii) avaliar a diversidade genética das mesmas para orientação de futuros cruzamentos. Para tal, dois ensaios (litoral e sertão do estado do Ceará) foram realizados em períodos distintos para a caracterização morfoagronômica de oito variedades tradicionais do estado do Ceará mais duas cultivares testemunhas. Ambos os ensaios foram realizados no delineamento em blocos ao acaso com quatro repetições. Adicionalmente, foi feita a caracterização molecular por marcadores ISSR. Devido a presença de interação genótipos por ambientes, observou-se que para as condições do litoral (Fortaleza), a variedade tradicional Boi Deitado foi a mais indicada, e para as condições do sertão (Madalena) foi a Vinagre Barrigudo de Caldo, por serem superiores quanto ao rendimento de grãos e quanto a outros caracteres agronômicos. Buscando ampliar a base genética do feijão-caupi, sugerem-se cruzamentos entre os genótipos Boi deitado e Cojó para a geração de populações segregantes em futuros programas de melhoramento.
\end{abstract}

Palavras-chave: Vigna unguiculata. Recursos genéticos. Caracterização morfoagronômica. Marcadores ISSR.

\footnotetext{
${ }^{*}$ Corresponding author

${ }^{1}$ Received for publication in $08 / 31 / 2018$; accepted in $07 / 11 / 2019$.

Paper extracted from the master dissertation of the first author.

${ }^{2}$ Department of Plant Science, Universidade Federal do Ceará, Fortaleza, CE, Brazil; lindabrenna@gmail.com - ORCID: 0000-0002-35543908, marcelospufc@gmail.com - ORCID: 0000-0002-1511-8808, lbcfiege@gmail.com - ORCID: 0000-0002-8752-7037, candida@ufc.br - ORCID: 0000-0003-2949-5660, juliodovale@ufc.br - ORCID: 0000-0002-3497-9793.
} 


\section{INTRODUCTION}

The cowpea [Vigna unguiculata (L.) Walp.] is a crop that plays an important role in human and animal nutrition in several countries (CHEN et al., 2017a), constituting an important food source for populations in Latin America, Asia and Africa (CHEN et al., 2017b; TAN et al., 2012). The species Fabaceae, with protein content in grains ranging from 22 to 30\% (MANDA et al., 2019; WENG et al., 2019), is traditionally cultivated in semi-arid regions, such as the Brazilian northeast (ANATALA et al., 2014) due to its high plasticity, especially to conditions with low water availability (RUSINAMHODZI et al., 2012).

The state of Ceará is the largest producer of cowpea in the Northeast of Brazil, with an estimated production volume of 105.7 thousand tons in the $2018 / 2019$ harvest. However, crop yields in the state are lowest in the region $\left(256 \mathrm{~kg} \mathrm{ha}^{-1}\right)$, the results are worse when compared to other producing regions of the country, such as the Midwest, which presents an average of $1146 \mathrm{~kg} \mathrm{ha}^{-1}$ (CONAB, 2019). This may be justified by some factors, such as: predominance of subsistence farming in the Northeast, inadequate supply of inputs and management, and use of varieties with low agronomic potential (DIAS; BERTINI; FREIRE FILHO, 2016). Thus, there is a need for greater technical assistance and development of cultivars adapted to the region (DA SILVA et al., 2018).

The Active Bank of cowpea germplasm of the Federal University of Ceará (BAG-Caupi) has 922 accessions of the species, and has contributed since its foundation to studies in diverse stages of crop improvement, which have already generated released cultivars, such as Seridó and Setentão (PAIVA et al., 2014). However, most farmers in the state still use landraces, prostrate and long-cycle varieties (SILVA et al., 2018), and adopt low-tech production systems. Thus, due to the genotype $\mathrm{x}$ production system interaction, there is a need for the development of cowpea cultivars specific for different cropping systems (DE OLIVEIRA et al., 2015) and these landraces should be studied for their productive potential.

Landraces consist of genotypes that have not improved or have not undergone conventional breeding, and are maintained and propagated by local farmers (FONSECA et al., 2015). These varieties, also denominated as crioula, preserve genetic variability of the species in terms of tolerance to biotic and abiotic factors and may help breeding programs in the development of more productive cultivars (CARVALHO et al., 2017). However, for this it is necessary to have access to this genetic patrimony often passed from generation to generation and, above all, to know it.
This patrimony becomes known through the characterization, but there is still little information in the literature regarding the landraces of cowpea. It was observed that the genetic potential of the species is little explored, considering that under experimental conditions the yields can exceed 2400 $\mathrm{kg} \mathrm{ha}^{-1}$ (CORREA et al., 2015; SILVA et al., 2018). However, the lack of characterization makes it difficult to exploit the potential of these genotypes. In this sense, studies of genetic divergence can contribute to the selection of genotypes with high productive potential (SANTOS et al., 2014a) and molecular markers are very efficient in these evaluations.

Several markers can be used to characterize genotypes and molecular markers, present fast and precise results which are uninfluenced by the environment (TANTASAWAT et al., 2010). Among the molecular markers, the ISSR (Inter Simple Sequence Repeat), although nonspecific, has a wide distribution in the genome of eukaryotes (OMONDI et al., 2016), high reproducibility and low cost, being widely used in studies to evaluate the diversity of genotypes of the species (ANATALA et al., 2014; GAJERA et al., 2014; TANTASAWAT et al., 2010).

Thus, the objectives of this study were: (i) to identify landraces of cowpea that have agronomic potential and (ii) to evaluate the genetic diversity of the cowpeas to guide future crosses.

\section{MATERIAL AND METHODS}

Two trials were carried out at distinct periods for the morphoagronomic characterization of eight landraces, using two cultivars (Table 1). The first experiment was conducted between April and August of 2016 in coastal conditions, Fortaleza-CE (344'25,8'S; 38 34'37,1'W; $6 \mathrm{~m}$ ), and the second experiment between February and June 2017 in sertão conditions, Madalena-CE (447'43,1's; 39³9'24,3”W; $357 \mathrm{~m}$ ).

Both trials were performed in the dryland, and during this period there was rainfall of $740.5 \mathrm{~mm}$ in Fortaleza and $399.8 \mathrm{~mm}$ in Madalena (FUNCEME, 2017). In the soil preparation of the areas, plowing and harrowing was performed. The fertilization was done according to the soil analysis (Madalena $=\mathrm{K}^{+}$: $0,31 \mathrm{cmol}_{\mathrm{c}} \mathrm{kg}^{-1}, \mathrm{P}_{\text {assimilable }}: 5 \mathrm{mg} \mathrm{kg}{ }^{-1}$; Fortaleza $=\mathrm{K}^{+}$: $\left.0,15 \mathrm{cmol}_{\mathrm{c}} \mathrm{kg}^{-1}, \mathrm{P}_{\text {assimilable: }} 59 \mathrm{mg} \mathrm{kg} \mathrm{kg}^{-1}\right)$ and the recommendations for the crop (CRAVO; VIÉGAS; BRASIL, 2007). In the planting, the fertilizer used were potassium chloride $\left(33.33 \mathrm{~kg} \mathrm{ha}^{-1}\right.$ in Madalena and $66.66 \mathrm{~kg} \mathrm{ha}^{-1}$ in Fortaleza) and simple superphosphate (333.33 kg ha $\mathrm{kg}^{-1}$ in Madalena). After fifteen days of sowing, nitrogen fertilization was performed by covering with urea $\left(43.48 \mathrm{~kg} \mathrm{ha}^{-1}\right.$ in both environments). 
L. B. R. ARAÚJO et al

Table 1. Identification and origin of the accessions of cowpea used in the tests carried out in Fortaleza-CE and in Madalena -CE.

\begin{tabular}{ccc}
\hline IDENTIFICATION & ACCESSIONS & ORIGIN \\
\hline Control cultivars & & Teresina - PI \\
\hline CE-934 & BRS-Guariba & Fortaleza - CE \\
CE-596 & Setentão & Quixadá - CE \\
\hline Landraces & & Unknown \\
CCB-060 & Pingo de Ouro - Quixadá & Quixeramobim - CE \\
CCB-058 & Cara de Gato & Choró - CE \\
CCB-012 & Raul & Tauá - CE \\
CCB-010 & Vinagre Barrigudo de Caldo & Quixadá - CE \\
CCB-015 & Cojó & Quixadá - CE \\
CCB-059 & Boi Deitado & Choró - CE \\
CCB-011 & Manteiguinha & Pingo de Ouro - Choró \\
\hline
\end{tabular}

CE: Ceará; CCB: Brazilian Crioula Cultivar. Identification of accessions of the Active Bank of cowpea Germoplasm of the Federal University of Ceará (BAG-Cowpea). (BAG-Cowpea).

The two experiments were carried out in a randomized complete block design with four replicates. Each experimental plot consisted of six plant rows of $1.0 \mathrm{~m}$ length spaced at $0.20 \mathrm{~m}$ between plants and $0.80 \mathrm{~m}$ between rows, having as a useful area four central rows (20 plants). The spacing between blocks was $2 \mathrm{~m}$.

During planting, three seeds were distributed per pit and 15 days after sowing, thinning was carried out, maintaining the most vigorous plant in each pit. The control of insects (caterpillars, aphids and bedbugs) was carried out by means of insecticides based on deltamethrin ( $3 \mathrm{~g}$ ai ha ${ }^{-1}$ ) during the thinning period, and cypermethrin ( $25 \mathrm{~g}$ ai $\mathrm{ha}^{-1}$ ) in the grain filling period.

\section{Morphoagronomic characterization of genotypes}

Sixteen descriptors were evaluated, 7 quantitative and 9 qualitative. The qualitative characters corresponded to: flower color, plant size, central leaflet shape, presence of anthocyanin in different parts of the plant (leaflet, petiole, petiole base, peduncle, peduncle base, pod, calyx, branches and stem), position of pod, pod color, pod shape, grain color and grain shape. The quantitative characters corresponded to: days until flowering, equivalent to $50 \%$ of flowering plants, cycle, length of pods, which corresponded to the average length of ten randomly selected pods, number of pods per plant, number of grains per pod, which corresponded to the average number of grains of the previously selected pods, mass of one hundred grains and yield, the latter being obtained by converting the value produced in the experimental area converted to $\mathrm{kg} \mathrm{ha}{ }^{-1}$.

The assumptions of normality and homoscedasticity of the residual variances were verified and, subsequently, the individual and joint variance analyses were performed for the quantitative characters. For the individual analysis of variance, we used the model $Y_{i j}=m+g_{i}+b_{j}+\varepsilon_{i j}$, where: $m$ is the general mean; $g_{i}$ is the effect of the $i-$ th genotype considered as fixed; $b_{j}$ is the effect of the $\mathrm{j}$-th block considered as random and $\varepsilon_{\mathrm{ij}}$ is the experimental error considered as random. For the joint analysis of variance, we used the model $\mathrm{Y}_{\mathrm{ij}}=\mathrm{m}$ $+b_{k}+g_{i}+a_{j}+g a_{i j}+\varepsilon_{i j k}$, where: $m$ is the general mean; $b_{k}$ is the effect of the k-th block declared as random; $g_{i}$ is the effect of the $i$-th genotype considered as fixed; $a_{j}$ is the effect of the $j$ th environment considered as fixed; $\mathrm{ga}_{\mathrm{ij}}$ is the effect of the interaction of the $\mathrm{i}$-th genotype with the $\mathrm{j}$-th environment considered as fixed and $\varepsilon_{\mathrm{ijk}}$ is the experimental random error. The averages were grouped by the Scott-Knott test at 5\% probability. The genotype interaction by environments was decomposed into a simple and a complex part (CRUZ; CASTOLDI, 1991). Quantitative traits/ characters were correlated using the Pearson correlation analysis. All analyses were performed using GENES software (CRUZ, 2013).

The results of the qualitative traits were divided into classes and the genetic distances between the individuals were estimated from the qualitative and quantitative traits according to the Gower algorithm (1971):

$$
\mathrm{D}_{\mathrm{ijk}}=\frac{\sum_{\mathrm{k}=1}^{\mathrm{p}} \mathrm{W}_{\mathrm{ijk}} \mathrm{S}_{\mathrm{ijk}}}{\sum_{\mathrm{k}=1}^{\mathrm{p}} \mathrm{W}_{\mathrm{ijk}}}
$$

Where $D_{i j k}$ is the genetic distance between individuals $\mathrm{i}$ and $\mathrm{j}$ for $\mathrm{k}$ characters, $\mathrm{W}_{\mathrm{ijk}}$ is the weight given to the combination ijk and $S_{i j k}$ is the contribution of $\mathrm{k}$ in the similarity between individuals $\mathrm{i}$ and $\mathrm{j}$, with values between 0 and 1 .

\section{Molecular characterization of genotypes}

For the molecular evaluations, young leaves of the genotypes were used for the extraction of genomic DNA by the protocol described by Doyle and Doyle (1990). The extracted DNA was quantified in NanoDrop 2000 spectrophotometer 
(Thermo Scientific ${ }^{\circledR}$ ), diluted to a concentration of $10 \mathrm{ng} / \mu \mathrm{L}$ and stored at $-20{ }^{\circ} \mathrm{C}$.

In the ISSR analyses, 25 initiators (Integrated DNA Technologies $\left.{ }^{\circ}\right)$ were used. In the amplification reactions were used: buffer $(1 \mathrm{X})$, dNTPs $(0.2 \mathrm{mM}), \mathrm{MgCl}_{2}(2 \mathrm{mM})$, initiator $(0.8 \mu \mathrm{M})$, Genomic DNA $(30 \mathrm{ng} / \mu \mathrm{L})$ and Taq DNA polymerase (1 unit) (GoTaq Flexi DNA Polymerase, Promega $\left.{ }^{\circledR}\right)$. The thermocycler THERM-1000 program (Axygen $\AA$ ) consisted of an initial denaturation of $94^{\circ} \mathrm{C}$ for 5 minutes and 40 cycles of denaturation, annealing and extension. Each cycle consisted of $94^{\circ} \mathrm{C}$ for 1 minute, $45,48,50$ or $55^{\circ} \mathrm{C}$ (according to the initiator used) for 30 seconds and $72^{\circ} \mathrm{C}$ for 1 minute. There was also a final extension of $72^{\circ} \mathrm{C}$ for 10 minutes and reduction to $4^{\circ} \mathrm{C}$. The temperature variations in the annealing phase occurred according to the best amplification for each of the primers.

The PCR products were subjected to $1.2 \%$ agarose gel electrophoresis, prepared with TBE buffer with a final concentration of $0.5 \mathrm{X}$. The electrophoresis was performed in a horizontal tank with an average running time of 1 hour ( 90 Volts). The gel images were captured on a Gel Logic 212 Pro (Carestream ${ }^{\circledR}$ ) photodocumentator after staining with ethidium bromide $(10 \mathrm{mg} / \mathrm{mL})$.

The photos of the electrophoresis gels were analyzed and from them a binary matrix was generated, where values 0 and 1 were assigned for the absence and presence of bands, respectively. The spreadsheet data were used in the GENES software (CRUZ, 2013) to perform the statistical analyses. Genetic dissimilarity was calculated using the complement of Jaccard (1901) similarity index:

$$
D_{i j}=\frac{a}{a+b+c}
$$

Where Dij is the genetic distance between individuals $i$ and $j, a$ corresponds to the presence of bands in individuals $i$ and $j, b$ corresponds to the presence of bands in individual $i$ and absence in individual $j$ and $c$ is the absence of bands in individual $i$ and presence in individual $j$.

\section{Analysis of genetic diversity}

From the dissimilarity matrices, constructed from the estimated genetic distances for the analyses with molecular markers, morphological descriptors (qualitative characters) and joint (morphological and molecular descriptors) dendrograms were created using the Mean Linkage method between groups (UPGMA). These analyses were performed using the software R version 3.4.0 (R CORE TEAM, 2017). The cophenetic correlation coefficient (r) was calculated to verify the adjustment of each graph to its matrix. The methodology described by Mojena (1977) was used to calculate the cutoff points.:

\section{$\mathrm{Pc}=\mathrm{m}+\mathrm{k} \cdot \mathrm{Dp}$}

Where: $\mathrm{Pc}$ is the cutoff point, $\mathrm{m}$ is the average, $\mathrm{K}$ is a constant (1.25) and $\mathrm{Dp}$ is the standard deviation

\section{RESULTS AND DISCUSSION}

There was a significant difference $(\mathrm{P}<0.01)$ among the genotypes for all quantitative characters evaluated in the Fortaleza assay (Table 2). In the Madalena assay, there was a significant difference (P $<0.01$ ) for six of the seven characters evaluated. This evidences the presence of genotypic differences among the cowpea landraces evaluated in the study and, therefore, the possibility of gains with the selection, as found in other studies of this nature (LOCATELLI et al., 2014; SANTOS et al., 2014a; SOUSA et al., 2015). The varieties presented similar performances regarding the cycle in the condition of Madalena, with an approximate average of 78 days.

The coefficients of experimental Variation $\left(\mathrm{CV}_{\mathrm{e}}\right)$ of the characters were similar between the two environments and presented magnitudes similar to those detected in other studies (SANTOS et al., 2014a; SANTOS et al., 2014b), suggesting reliability in the estimates obtained. These coefficients ranged from 4.52 to $25.61 \%$ in Fortaleza and from 3.12 to $22.44 \%$ in Madalena. The highest estimates were observed for characters such as the number of pods per plant and productivity. Almeida et al. (2012) and Torres et al. (2015) observed similar results when evaluating the yield of the crop, which is expected because of the quantitative nature of these characteristics, thus being highly influenced by environmental conditions. 
L. B. R. ARAÚJO et al.

Table 2. Summary of analyses of individual variances and estimates of some genetic parameters for the characters days to flowering (DAF) in days, cycle (CIC) in days, length of pods (CVa) in $\mathrm{cm}$, number of pods per plant (NVP), number of grains per pod (NGV), weight of one hundred grains (M100G) in grams and yield (PROD) in $\mathrm{kg} \mathrm{ha}^{-1}$.

\begin{tabular}{|c|c|c|c|c|c|c|c|c|}
\hline \multicolumn{9}{|c|}{ Mean squares } \\
\hline FV & GL & DAF & $\mathrm{CIC}$ & $\mathrm{CVa}$ & NVP & NGV & $\mathrm{M}_{100} \mathrm{G}$ & PROD \\
\hline \multicolumn{9}{|c|}{-----------------------------------------------------Trials in Fortaleza------------------------------------------------ } \\
\hline Blocks & 3 & 7.73 & 310.47 & 3.90 & 20.87 & 0.61 & 0.94 & 302922 \\
\hline Genotype & 9 & $90.18^{* *}$ & $688.00^{* *}$ & $22.27^{* *}$ & $54.38^{* *}$ & $6.93^{* *}$ & $13.60^{* *}$ & $737254^{* *}$ \\
\hline Residue & 27 & 16.55 & 133.65 & 1.09 & 8.68 & 0.42 & 0.83 & 65844 \\
\hline $\mathrm{CV}_{\mathrm{e}}(\%)$ & & 8.76 & 11.74 & 5.28 & 25.61 & 5.55 & 4.52 & 20.47 \\
\hline $\mathrm{CV}_{\mathrm{g}}(\%)$ & & 9.24 & 11.95 & 11.60 & 29.38 & 10.91 & 8.89 & 32.69 \\
\hline $\mathrm{CV}_{\mathrm{g}} / \mathrm{CV}_{\mathrm{e}}$ & & 1.05 & 1.01 & 2.19 & 1.15 & 1.96 & 1.96 & 1.59 \\
\hline Mean & & 46.4 & 98.5 & 19.82 & 11.50 & 11.68 & 20.10 & 1253 \\
\hline \multicolumn{9}{|c|}{---------------------------------------------------Trials in Madalena------- } \\
\hline Blocks & 3 & 3.96 & 3.29 & 0.56 & 133.30 & 0.77 & 0.43 & 4390859 \\
\hline Genotype & 9 & $34.58^{* *}$ & $101.07^{\text {ns }}$ & $13.63^{* *}$ & $32.22^{* *}$ & $6.57^{* *}$ & $19.99^{* *}$ & $1002056^{* *}$ \\
\hline Residue & 27 & 1.96 & 57.74 & 0.97 & 9.33 & 1.49 & 1.47 & 230515 \\
\hline $\mathrm{CV}_{\mathrm{e}}(\%)$ & & 3.12 & 9.63 & 4.80 & 22.44 & 7.96 & 5.57 & 21.34 \\
\hline $\mathrm{CV}_{\mathrm{g}}(\%)$ & & 6.38 & 4.17 & 8.66 & 17.58 & 7.35 & 9.87 & 19.52 \\
\hline $\mathrm{CV}_{\mathrm{g}} / \mathrm{CV}_{\mathrm{e}}$ & & 2.04 & 0.43 & 1.80 & 0.78 & 0.92 & 1.77 & 0.91 \\
\hline Mean & & 44.7 & 78.9 & 20.51 & 13.60 & 15.32 & 21.78 & 2249 \\
\hline \multicolumn{9}{|c|}{ 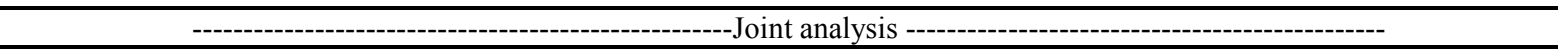 } \\
\hline Blocks & 3 & 0.64 & 136.81 & 1.37 & 98.79 & 0.36 & 0.69 & 2570339 \\
\hline Genotype (G) & 9 & $112.78^{* *}$ & $583.03^{* *}$ & $34.63^{* *}$ & $12.58^{\mathrm{ns}}$ & $12.58^{* *}$ & $28.16^{* *}$ & $559653^{*}$ \\
\hline Environment (A) & 1 & $56.11^{\mathrm{ns}}$ & $7702.81^{* *}$ & $9.58^{* *}$ & $88.31^{* *}$ & $260.53^{* *}$ & $57.03^{* *}$ & $19855433^{* *}$ \\
\hline Int. GxA & 33 & $11.97^{\mathrm{ns}}$ & $206.03^{*}$ & $1.27^{\mathrm{ns}}$ & $74.02^{* *}$ & $0.82^{\mathrm{ns}}$ & $5.43^{* *}$ & $1179657^{* *}$ \\
\hline Residue & 57 & 16.14 & 99.97 & 1.14 & 11.44 & 0.97 & 1.12 & 252140 \\
\hline \multicolumn{9}{|c|}{ Parts of the interaction (\%) } \\
\hline Complex & & 14.17 & 19.49 & 12.10 & 129.10 & 35.20 & 52.50 & 115.65 \\
\hline Simple & & 85.83 & 80.51 & 87.90 & & 64.80 & 47.40 & \\
\hline
\end{tabular}

${ }^{\mathrm{ns}}$ Not significant by $\mathrm{F}$ Test.**and *significant at $1 \%$ and $5 \%$ probability, respectively, by $\mathrm{F}$ test.

The decomposition of the interaction showed that all the characters presented part of the interaction of the complex type, and the characters number of pods per plant and productivity present only this type of interaction, which justifies the fact that accessions perform differently in environments. When the interaction of the complex type is more expressive for a given character, the decision of the breeder becomes more difficult and the accessions must be selected for the specific environment of better performance, due to its greater adaptation to this (NUNES et al., 2002). The presence of complex interaction reflects in the relative position of accessions in the evaluated environments (GARBUGLIO et al., 2007) and this can be observed in the present study (Table 3 ).

The $\mathrm{CVg} / \mathrm{CVe}$ ratios for all characters were higher than one unit in the Fortaleza assay, revealing favorable conditions for selection in this locality. In Madalena, only days until flowering, length of the pod and mass of one hundred grains were shown to be suitable for selection. The other characters had their expressions more influenced by the environment, evidenced by CVe. On the other hand, the highest estimates of the coefficients of genotypic variation were observed for number of pods per plant and productivity, regardless of the locality, evidencing high genetic variability for both.

A significant effect was observed in $G \times A$ interaction for most of the evaluated characters (Table 2). This means that cowpea varieties had different relative responses in Fortaleza and Madalena, except for days until flowering, length of pods and number of grains per pod. According to the Köppen classification, the climate of Fortaleza is the tropical rainy type Aw' and that of Madalena is the semi-arid hot type Bsh'w', which generates great variations in rainfall, temperature, humidity and other elements. The two environments represent the predominant climates in the state of Ceará (OLIVEIRA; ARRAES; VIANA, 2013), and the Fortaleza environment represents the coastal region of the state and the environment Madalena represents the region of the Ceará sertão.

However, one of the factors that most influences the anticipation or delay of flowering is the photoperiod. Although the localities present different weather conditions, the photoperiod is constant in both and, most likely, this must have contributed to similar responses of the varieties. On the other hand, for the characters length of pods and number of grains per pod, the interactions between genotypes and environments were not crucial to promote differences in the responses of the varieties.

The non-significant effect of $G \times A$ interaction for the characters days up to flowering, pods length and number of grains per pod suggests a more comprehensive indication, from the evaluation 
of the averages for the two environments. These characters are the most reliable for the differentiation of the varieties, due to the lower interaction presented in the environments (TORRES et al., 2015). For the character days until flowering, the varieties that presented lower averages should be prioritized. This is because the number of days which elapsed from emergence to flowering is related to the precocity (SILVA; RAMALHO; ABREU, 2007), an important feature especially for semiarid regions (EHLERS; HALL, 1997). Thus, the cultivars BRS Guariba and Setentão, and the traditional varieties
Pingo de Ouro-Quixadá and Manteiguinha are the ones indicated for this character (Table 3). For the character length of pods, the varieties must present the commercial standard of $20 \mathrm{~cm}$ (DE OLIVEIRA et al., 2015). In this case, the varieties Pingo de Ouro - Quixadá, Boi Deitado, Manteiguinha and Pingo de Ouro - Choró are the most suitable for both environments. For the number of grains per pod, the varieties Pingo de Ouro - Quixadá, Cara de Gato and Boi Deitado were the ones that stood out most for mutual selection.

Table 3. Estimates of averages per environment for the characters days to flowering (DAF) in days, cycle (CIC) in days, length of pods $(\mathrm{CVa})$ in $\mathrm{cm}$, number of pods per plant (NVP), number of grains per pod (NGV), mass of one hundred grains (M100G) in grams and yield (PROD) in $\mathrm{kg} \mathrm{ha}^{-1}$.

\begin{tabular}{|c|c|c|c|c|c|c|c|}
\hline ACCESSIONS & DAF & $\mathrm{CIC}$ & $\mathrm{CVa}$ & NVP & NGV & $\mathrm{M}_{100} \mathrm{G}$ & PROD \\
\hline \multicolumn{8}{|c|}{------------------------------------------Trials in Fortaleza-------------------------------------- } \\
\hline BRS-Guariba & $41.5 \mathrm{c}$ & $81.0 \mathrm{~b}$ & $18.1 \mathrm{~d}$ & $8.6 \mathrm{~b}$ & $9.2 \mathrm{c}$ & $18.9 \mathrm{~d}$ & $1614 a$ \\
\hline Setentão & $41.3 \mathrm{c}$ & $88.8 \mathrm{~b}$ & $16.8 \mathrm{~d}$ & $15.4 \mathrm{a}$ & $11.5 \mathrm{~b}$ & $17.9 \mathrm{~d}$ & $732 \mathrm{c}$ \\
\hline Pingo de Ouro - Quixadá & $42.5 \mathrm{c}$ & $89.0 \mathrm{~b}$ & $20.8 \mathrm{~b}$ & $9.8 \mathrm{~b}$ & $13.2 \mathrm{a}$ & $19.2 \mathrm{c}$ & $1284 b$ \\
\hline Cara de gato & $46.3 b$ & $108.0 \mathrm{a}$ & $19.7 \mathrm{c}$ & $13.4 \mathrm{a}$ & $13.1 \mathrm{a}$ & $18.0 \mathrm{~d}$ & $1558 \mathrm{a}$ \\
\hline Raul & $51.8 \mathrm{a}$ & $104.8 \mathrm{a}$ & $18.3 \mathrm{~d}$ & $9.6 \mathrm{~b}$ & $11.5 \mathrm{~b}$ & $21.2 \mathrm{~b}$ & $828 \mathrm{c}$ \\
\hline Vinagre barrigudo de caldo & $53.0 \mathrm{a}$ & $123.8 \mathrm{a}$ & $17.5 \mathrm{~d}$ & $8.0 \mathrm{~b}$ & $11.3 \mathrm{~b}$ & $23.3 \mathrm{a}$ & $920 \mathrm{c}$ \\
\hline Cojó & $52.5 \mathrm{a}$ & $100.0 \mathrm{a}$ & $18.9 \mathrm{c}$ & $10.2 \mathrm{~b}$ & $11.1 \mathrm{~b}$ & $22.8 \mathrm{a}$ & $1161 b$ \\
\hline Boi deitado & $46.5 b$ & $108.5 \mathrm{a}$ & $24.2 \mathrm{a}$ & $17.3 \mathrm{a}$ & $13.5 \mathrm{a}$ & $20.2 \mathrm{c}$ & $1843 \mathrm{a}$ \\
\hline Manteiguinha & $41.3 \mathrm{c}$ & $85.0 \mathrm{~b}$ & $22.0 \mathrm{~b}$ & $6.8 \mathrm{~b}$ & $10.6 \mathrm{~b}$ & $19.7 \mathrm{c}$ & $791 \mathrm{c}$ \\
\hline Pingo de Ouro - Choró & $47.5 \mathrm{~b}$ & $96.3 \mathrm{~b}$ & $21.9 \mathrm{~b}$ & $15.9 \mathrm{a}$ & $12.0 \mathrm{~b}$ & $19.9 \mathrm{c}$ & $1802 \mathrm{a}$ \\
\hline General mean & 46.4 & 98.5 & 19.8 & 11.5 & 11.7 & 20.1 & 1253 \\
\hline \multicolumn{8}{|c|}{----------------------------------------------Trials in Madalena------------------------------------------} \\
\hline BRS-Guariba & $40.8 \mathrm{c}$ & $70.8 \mathrm{a}$ & $19.1 \mathrm{c}$ & $18.4 \mathrm{a}$ & $12.9 \mathrm{~b}$ & $20.6 \mathrm{c}$ & $2108 b$ \\
\hline Setentão & $41.8 \mathrm{c}$ & $76.5 \mathrm{a}$ & $18.0 \mathrm{c}$ & $14.1 \mathrm{a}$ & $14.5 \mathrm{~b}$ & $20.5 \mathrm{c}$ & $1802 b$ \\
\hline Pingo de Ouro - Quixadá & $42.5 \mathrm{c}$ & $83.3 \mathrm{a}$ & $21.7 \mathrm{~b}$ & $15.5 \mathrm{a}$ & $16.9 \mathrm{a}$ & $19.8 \mathrm{c}$ & $2937 a$ \\
\hline Cara de gato & $45.3 \mathrm{~b}$ & $80.3 \mathrm{a}$ & $21.1 \mathrm{~b}$ & $12.2 \mathrm{~b}$ & $16.4 \mathrm{a}$ & $18.8 \mathrm{c}$ & $2111 b$ \\
\hline Raul & $45.8 \mathrm{~b}$ & $83.0 \mathrm{a}$ & $19.2 \mathrm{c}$ & $13.6 \mathrm{a}$ & $16.0 \mathrm{a}$ & $22.8 \mathrm{~b}$ & $2192 b$ \\
\hline Vinagre barrigudo de caldo & $49.3 \mathrm{a}$ & $83.3 \mathrm{a}$ & $19.6 \mathrm{c}$ & $15.7 \mathrm{a}$ & $15.9 \mathrm{a}$ & $25.2 \mathrm{a}$ & $3287 \mathrm{a}$ \\
\hline Cojó & $47.5 \mathrm{a}$ & $77.3 \mathrm{a}$ & $19.0 \mathrm{c}$ & $11.0 \mathrm{~b}$ & $14.5 b$ & $22.0 \mathrm{~b}$ & $1668 b$ \\
\hline Boi deitado & $47.5 \mathrm{a}$ & $86.0 \mathrm{a}$ & $24.1 \mathrm{a}$ & $8.9 \mathrm{~b}$ & $16.1 \mathrm{a}$ & $25.8 \mathrm{a}$ & $1999 b$ \\
\hline Manteiguinha & $41.5 \mathrm{c}$ & $73.5 \mathrm{a}$ & $21.6 b$ & $15.6 \mathrm{a}$ & $14.0 \mathrm{~b}$ & $21.1 \mathrm{~b}$ & $2364 b$ \\
\hline Pingo de Ouro - Choró & $45.5 b$ & $74.8 \mathrm{a}$ & $21.9 \mathrm{~b}$ & $11.1 \mathrm{~b}$ & $16.1 \mathrm{a}$ & $21.4 \mathrm{~b}$ & $2029 b$ \\
\hline General mean & 44.7 & 78.8 & 20.5 & 13.6 & 15.3 & 21.8 & 2250 \\
\hline
\end{tabular}

Means followed by the same letter in the column do not differ from each other by Scott-Knott's test at $5 \%$ probability.

In general, the varieties of cowpea presented superior performance in the conditions of Madalena (Table 3), being more productive and precocious. This is likely to be a reflection of the greater adaptation of the landraces to the hot semiarid climate, which occurs in the municipalities of collection of the accessions and in Madalena, and which has a direct relationship with rainfall, that was found in this environment the ideal range for the crop (250-400 mm) (BASTOS; ANDRADE JÚNIOR; NOGUEIRA, 2017), but in Fortaleza it was much higher, reaching $740.5 \mathrm{~mm}$ during cultivation.

In relation to the cycle, the earliest genotypes, in addition to the cultivars, were the Pingo de OuroQuixadá, Manteiguinha and Pingo de Ouro-Choró varieties in the Fortaleza conditions. For Madalena, the genotypes did not present distinct behavior regarding the expression of this character (Tables 2 and 3). The genotypes that presented the highest number of pods per plant in Fortaleza were the cultivar Setentão and the landraces Cara de Gato, Boi Deitado and Pingo de Ouro - Choró. In Madalena, in addition to the controls, the Pingo de Ouro varieties Quixadá, Raul, Vinagre Barrigudo de Caldo and Manteiguinha were highlighted.

A significant correlation was observed with high magnitude between the characters days until flowering and cycle, revealing that the selection based on the smallest number of days until flowering can be efficient to find precocious accessions (Table 4). The cycle also presented positive correlation with the number of grains per pod and the mass of one hundred grains, thus, later accessions tend to be more productive, as already observed by Correa et al. (2012) when working with cowpea, and confirmed in this study when we visualized a positive correlation 
between the number of grains per pod and productivity. In this case, the productivity character, considered complex, was directly influenced by the number of grains per pod, and this may facilitate the improvement of the crop, generating good results in yield, due to the magnitude of the selection, in a shorter period of time. Positive correlations were also observed among these characters by Correa et al. (2012) for the species.

Table 4. Pearson correlation coefficients for the descriptors days until flowering (DAF), cycle (CIC), number of grains per pod $(\mathrm{NGV})$, length of pods (CVa), mass of one hundred grains (M100G), number of pods per plant (NVP) and productivity (PROD).

\begin{tabular}{|c|c|c|c|c|c|c|}
\hline & $\mathrm{CIC}$ & NGV & $\mathrm{CVa}$ & $\mathrm{M}_{100} \mathrm{G}$ & NVP & PROD \\
\hline DAF & $0.8264^{* *}$ & $0.3466^{\mathrm{ns}}$ & $-0.0474^{\mathrm{ns}}$ & $0.7817^{* *}$ & $-0.5124^{\mathrm{ns}}$ & $0.1544^{\mathrm{ns}}$ \\
\hline $\mathrm{CIC}$ & & $0.6367^{*}$ & $0.1100^{\mathrm{ns}}$ & $0.6526^{*}$ & $-0.2642^{\mathrm{ns}}$ & $0.5192^{\mathrm{ns}}$ \\
\hline NGV & & & $0.4900^{\mathrm{ns}}$ & $0.0618^{\mathrm{ns}}$ & $0.0566^{\mathrm{ns}}$ & $0.7317^{*}$ \\
\hline $\mathrm{CVa}$ & & & & $0.0727^{\mathrm{ns}}$ & $-0.0413^{\mathrm{ns}}$ & $0.3860^{\mathrm{ns}}$ \\
\hline $\mathrm{M}_{100} \mathrm{G}$ & & & & & $-0.4898^{\mathrm{ns}}$ & $0.1264^{\mathrm{ns}}$ \\
\hline NVP & & & & & & $0.2562^{\mathrm{ns}}$ \\
\hline
\end{tabular}

${ }^{\text {ns Not significant. }}{ }^{* *}$ and $*$ significant at $1 \%$ and $5 \%$ probability.

The superiority of the Boi deitado variety shows well this correlation in Fortaleza, since it presented an above average performance, producing more than 2.5 times that produced by the Setentão control cultivar. Therefore, it is an accession that deserves attention and certainly presents agronomic potential to be cultivated under edaphoclimatic conditions similar to Fortaleza.

In the conditions of Madalena, the varieties that presented more prominence for the productivity character were the vinagre Barrigudo de Caldo and the Pingo de Ouro-Quixadá. Both were also highlighted as the number of grains per pod. The vinagre Barrigudo de Caldo variety presents a very interesting phenotypic set, with intermediate cycle, pod length normally required by the producers and with a high number of pods per plant. Thus, it is verified that for both localities and, consequently, for the two predominant climates of the state of Ceará, different varieties should be indicated.

In both trials, the average productivity of the landraces evaluated was higher than the average for the state of Ceará $\left(256 \mathrm{~kg} \mathrm{ha}{ }^{-1}\right)$ and Brazil (491.45 $\mathrm{kg} \mathrm{ha}^{-1}$ ) (CONAB, 2019). This proves the potential of these varieties when cultivated under suitable fertilization conditions.

In relation to the qualitative characteristics evaluated, the genotypes presented different patterns, generating a total of 3 classes for flower color, 7 for grain color, 3 for grain shape, 3 for central leaflet shape, 3 for pod color, 2 for pod shape, 2 for pod position, 3 for plant size and 2 for pigmentation of different parts of the plant (Tables 5 and 6). Thus, the character with the greatest variation was the color of the grain and the ones of smaller variation were the shape of the pod, position of the pod and pigmentation.

Table 5. Characterization of cowpea varieties and cultivars evaluated for flower color, grain color, grain shape, central leaflet shape, pod color, pod shape, pod position and plant size.

\begin{tabular}{|c|c|c|c|c|c|c|c|c|}
\hline ACCESSIONS & $\mathrm{CF}$ & $\mathrm{CG}$ & FG & FFC & $\mathrm{CV}$ & $\mathrm{FV}$ & PV & $\mathrm{PP}$ \\
\hline BRS-Guariba & $\mathrm{Br}$ & $\mathrm{Br}$ & $\mathrm{Ov}$ & Sl & $\mathrm{Rj}$ & $\mathrm{RC}$ & $\mathrm{AF}$ & $\mathrm{Se}$ \\
\hline Setentão & $\mathrm{Vi}$ & Es & Ro & So & $\mathrm{Am}$ & $\mathrm{RC}$ & DF & $\mathrm{Se}$ \\
\hline Pingo de Ouro - Quixadá & Vi & $\mathrm{Ma}$ & Ro & Sl & $\mathrm{Rj}$ & $\mathrm{CC}$ & $\mathrm{AF}$ & $\mathrm{Sp}$ \\
\hline Cara de gato & $\mathrm{ViC}$ & $\mathrm{BrPr}, \mathrm{BrHPr}, \mathrm{Pr}, \mathrm{Br}$ & Ro & S1 & Rs & $\mathrm{CC}$ & DF & $\operatorname{Pr}$ \\
\hline Raul & $\mathrm{Vi}$ & $\mathrm{Ma}$ & Ro & $\mathrm{O}$ & Rs & $\mathrm{CC}$ & DF & $\operatorname{Pr}$ \\
\hline Vinagre barrigudo de caldo & $\mathrm{Vi}$ & Vi & Ro & $\mathrm{O}$ & Rs & $\mathrm{RC}$ & $\mathrm{DF}$ & $\operatorname{Pr}$ \\
\hline Cojó & Vi & $\mathrm{Ma}$ & Ro & $\mathrm{O}$ & $\mathrm{Rj}$ & $\mathrm{CC}$ & DF & $\operatorname{Pr}$ \\
\hline Boi deitado & $\mathrm{ViC}$ & BrMa & $\mathrm{Ov}$ & So & Rs & $\mathrm{RC}$ & $\mathrm{AF}$ & $\operatorname{Pr}$ \\
\hline Manteiguinha & $\mathrm{Br}$ & BrHMa & $\operatorname{Re}$ & S1 & $\mathrm{Rj}$ & $\mathrm{CC}$ & $\mathrm{AF}$ & $\mathrm{Se}$ \\
\hline Pingo de Ouro - Choró & $\mathrm{Vi}$ & $\mathrm{Ma}$ & $\mathrm{Ov}$ & S1 & $\mathrm{Rj}$ & $\mathrm{RC}$ & $\mathrm{AF}$ & $\mathrm{Se}$ \\
\hline
\end{tabular}

Legend: Colour of flower $(\mathrm{CF})$ - $\mathrm{Br}$ - white, $\mathrm{Vi}$ - violet and $\mathrm{ViC}$ - light violet; Colour of grain $(\mathrm{CG})$ - $\mathrm{Br}$ - white, Es green, Ma - brown, BrPr - white-black, BrHPr - white with black halo, Pr - black, Vi - vinagre, BrMa - white-brown and BrHMa - white with brown halo; Grain form (FG) - Ov - ovoid, Ro - rhomboid and Re - reniform; Form of the central follicle (FFC) - O - oval, So - semioval and Sl - semilanceolate; (CV) Am - yellow, Rs - pink and Rj - cracked; Pod shape (VF) - RC - cylindrical straight and CC - cylindrical curve; Pod position (PV) - AF - above foliage and DF different foliage levels; Plant Size (PP)-Se - Semierect, $\mathrm{Sp}$ - Semiprostrate and $\mathrm{Pr}$ - prostrate. 
L. B. R. ARAÚJO et al.

Table 6. Characterization of cowpea varieties and cultivars evaluated for the presence of anthocyanin pigmentation.

\begin{tabular}{|c|c|c|c|c|c|c|c|c|c|}
\hline \multirow[t]{2}{*}{ ACCESSIONS } & \multicolumn{9}{|c|}{ PIGMENTATION } \\
\hline & $\mathrm{F}$ & $\mathrm{P}$ & $\mathrm{BP}$ & $\mathrm{Pd}$ & $\mathrm{BPd}$ & $\mathrm{V}$ & $\mathrm{Cal}$ & $\mathrm{R}$ & $\mathrm{Cau}$ \\
\hline BRS-Guariba & $\mathrm{Pr}$ & $\operatorname{Pr}$ & $\operatorname{Pr}$ & $\mathrm{Pr}$ & $\mathrm{Pr}$ & $\operatorname{Pr}$ & $\operatorname{Pr}$ & $\operatorname{Pr}$ & $\operatorname{Pr}$ \\
\hline Setentão & At & At & $\operatorname{Pr}$ & $\operatorname{Pr}$ & $\operatorname{Pr}$ & At & At & $\operatorname{Pr}$ & $\operatorname{Pr}$ \\
\hline Pingo de Ouro - Quixadá & $\operatorname{Pr}$ & At & $\operatorname{Pr}$ & $\operatorname{Pr}$ & $\operatorname{Pr}$ & $\operatorname{Pr}$ & $\operatorname{Pr}$ & $\operatorname{Pr}$ & $\operatorname{Pr}$ \\
\hline Cara de gato & $\operatorname{Pr}$ & $\operatorname{Pr}$ & $\operatorname{Pr}$ & $\operatorname{Pr}$ & $\operatorname{Pr}$ & $\operatorname{Pr}$ & At & At & $\operatorname{Pr}$ \\
\hline Raul & At & At & At & At & At & At & At & $\operatorname{Pr}$ & At \\
\hline Vinagre barrigudo de caldo & At & At & $\operatorname{Pr}$ & At & $\operatorname{Pr}$ & At & At & $\operatorname{Pr}$ & $\operatorname{Pr}$ \\
\hline Cojó & $\operatorname{Pr}$ & At & At & $\operatorname{Pr}$ & $\operatorname{Pr}$ & At & At & At & At \\
\hline Boi deitado & $\operatorname{Pr}$ & At & At & At & At & At & At & $\operatorname{Pr}$ & At \\
\hline Manteiguinha & $\operatorname{Pr}$ & $\operatorname{Pr}$ & $\operatorname{Pr}$ & $\operatorname{Pr}$ & $\operatorname{Pr}$ & $\operatorname{Pr}$ & $\operatorname{Pr}$ & $\operatorname{Pr}$ & $\operatorname{Pr}$ \\
\hline Pingo de Ouro - Choró & $\operatorname{Pr}$ & At & $\operatorname{Pr}$ & $\operatorname{Pr}$ & $\operatorname{Pr}$ & $\operatorname{Pr}$ & $\operatorname{Pr}$ & $\operatorname{Pr}$ & $\operatorname{Pr}$ \\
\hline
\end{tabular}

Leaflet (F), Petiole (P), Base of petiole (BP), Peduncle (Pd), Base of peduncle (BPd), pod (V), Calyx (Cal), Branches $(\mathrm{R})$ and Stem $(\mathrm{Cau})$ : Absent (At) and Present (Pr).

The genotypes presented three commercial classes for cowpea, belonging to the white class cultivar BRS-Guariba and the variety Manteiguinha; to the class colors to cultivate Setentão and the varieties Pingo de Ouro - Quixadá, Raul, Vinagre Barrigudo de Caldo, Cojó, Boi Deitado, and Pingo de Ouro - Choró; and to a mixed class the variety Cara de Gato. Because they presented great variation, the colors of the grains contributed considerably to evaluation of the genetic diversity of the genotypes. There are regional preferences regarding grain color, with the predominance of the sub-classes Plain Mulatto, Plain White, Rugged White, Canapu and Evergreen (FREIRE FILHO et al., 2011). In the state of Ceará, the preference for grains of brown or mulatto color is clear.

The predominant classes for the evaluated characters were brown grain color, violet flower color, rhomboid grain shape, semi-lanceolate central leaflet shape, split pod color, and prostrate plant size (Table 5). The two classes for pod shape and position were presented in the same proportion and pigmentation because the presence of anthocyanin was more in the leaflets, base of petioles, peduncles, base of peduncles, branches and stems, showing great variation among the genotypes studied (Table $6)$.

From the evaluation of the qualitative traits presented in the study and the molecular evaluation by ISSR markers, it was possible to infer about the genetic diversity existing among the genotypes. The sixteen primers used in the present study generated amplification and, among these, fourteen were polymorphic and two monomorphic, amplifying a total of 85 bands. Thus, six groups of individuals were formed, which had a mean genetic distance of 0.1480 in the Dendrogram based on the molecular characteristics (Figure 1-A).
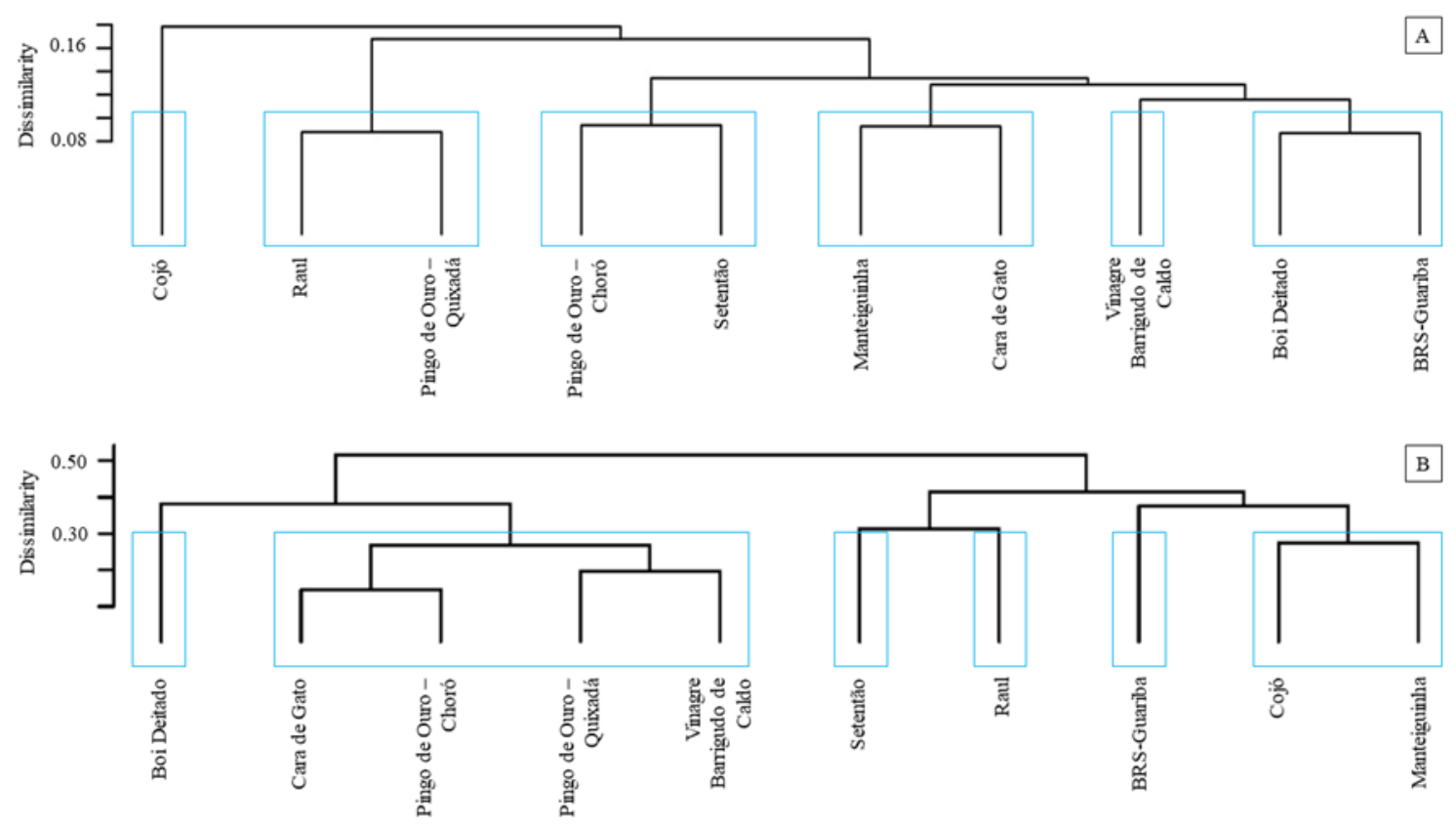

Figure 1. Dendrogram of genetic dissimilarity based on (A) molecular characters and (B) morphological and agronomic characters. 
The dendrogram based on morphological and agronomic characters evaluated (Figure 1 - B) allowed the formation of six distinct groups, which presented an average genetic distance of 0.4366 . The formation of the same number of groups for the morphoagronomic and molecular analysis was observed, although there was no coincidence in the formation of any of the groups in the two dendrograms.

For all the molecular markers, it was possible to find similarities between the genotypes capable of grouping them where only morphological characters were not possible, since four accessions remained alone according to the grouping by morphoagronomic characters and only two by molecular markers. This can be explained by the large amount of information generated by ISSR molecular markers that, because they are distributed throughout the genome of the individuals, have high discriminatory capacity (OMONDI et al., 2016), showing differences not detected by morphological markers, and corroborates with Gajera et al. (2014) who cited that Cowpea has a narrow genetic base although it has great phenotypic variability for some morphological characters, such as seed color, visualized in this study.

The cophenetic correlation coefficients (CCC) of the dendrograms presented values higher than 0.7 ( 0.8026 and 0.8111 for the dendrograms with molecular data and for the morphological and agronomic ones, respectively), a limit established by ROHLF (1970) for the adequacy of the grouping method. Thus, the results generated show a good representation of the genetic diversity of the accessions, which is a prerequisite for the genetic improvement of a crop and, therefore, must be used in a rational way, which can only be done through the knowledge of this diversity by means of characterizations (STOILOVA; PEREIRA, 2013).

Evaluation of the dendrograms suggests the generation of base populations with greater variability in breeding programs, crosses between the accessions of greater genetic distance, which are Cojó and Boi deitado. The accession Boi deitado presented the best productive performance in Fortaleza and a close value in Madalena, demonstrating a lower interaction with environment and a predictable behavior for this character. While the accession Cojó presents Brown tegument coloration, preferred by consumers in Ceará. Thus, the molecular and morphoagronomic genetic divergence data were complementary in this study.

\section{CONCLUSION}

For Fortaleza, the most indicated traditional variety is Boi deitado, while for Madalena, it is the Vinagre Barrigudo de Caldo, because they are productive in the respective environments and present favorable phenotypic expressions for the other agronomic characters

In order to increase the genetic base of cowpea, we suggest crosses between the most divergent genotypes, Cojó and Boi deitado, in the generation of segregating populations of future breeding programs.

\section{REFERENCES}

ALMEIDA, W. S. DE et al. Adapatibility and stability of grain yield in cowpea under different biometrics. Revista Brasileira de Agrociência, v. 18 , n. 2-4, p. 221-228, 2012.

ANATALA, T. J. et al. Comparison of ISSR and SSR markers for characterization of cowpea (Vigna unguiculata L.) genotypes. Indian Journal of Agricultural Biochemistry, v. 27, n. 2, p. 145-150, 2014.

BASTOS, E. A.; ANDRADE JÚNIOR, A. S.; NOGUEIRA, C. C. P. Cultivo de Feijão-Caupi. Disponível em: <https://ainfo.cnptia.embrapa.br/ digital/bitstream/item/161199/1/

SistemaProducaoCaupiCapituloIrrigacao.pdf $>$.

Acesso em: 05 jun. 2019.

CARVALHO, M. et al. European cowpea landraces for a more sustainable agriculture system and novel foods. Journalof the Science of Food and Agriculture, v. 97, n. 13, p. 4399-4407, 2017.

CHEN, H. et al. De novo transcriptomic analysis of cowpea (Vigna unguiculata L. Walp.) for genic SSR marker development. BMC Genetics, v. 18, n. 65, p. 1-12, 2017a.

CHEN, H. et al. Genetic diversity and a population structure analysis of accessions in the Chinese cowpea [Vigna unguiculata (L.) Walp.] germplasm collection. The Crop Journal, v. 5, n. 6, p. 363-372, $2017 b$.

COMPANHIA NACIONAL DE ABASTECIMENTO - CONAB. Acompanhamento safra brasileira grãos, v. 6 - Safra 2018/19 - Nono levantamento, Brasília, p. 1-113, junho 2019.

CORREA, A. M. et al. Estimativas de parâmetros genéticos e correlações entre caracteres fenológicos e morfoagronômicos em feijão-caupi. Revista Ceres, v. 59, n. 1, p. 88-94, 2012.

CORREA, A. M. et al. Variabilidade genética e correlações entre caracteres de feijão-caupi. Revista Agro@mbiente On-line, v. 9, n. 1, p. 42-47, 2015.

CRAVO, M. S.; VIÉGAS, I. J. M.; BRASIL, E. C. 
Recomendações de adubação e calagem para o Estado do Pará. 1. ed. Belém, PA: Embrapa Amazônia Oriental, 2007. 34 p.

CRUZ, C. D. GENES - a software package for analysis in experimental statistics and quantitative genetics. Acta Scientiarum, v. 35, n. 3, p. 271-276, 2013.

CRUZ, C. D.; CASTOLDI, F. L. Decomposição da interação genótipos $\mathrm{x}$ ambientes em partes simples e complexa. Ceres, v. 38, n. 219, p. 422-430,1991.

DA SILVA, A. C. et al. Diagnóstico da produção de feijão-caupi no nordeste brasileiro. Revista da Universidade Vale do Rio Verde, v. 16, n. 2, p. 15,2018 .

DE OLIVEIRA, E. et al. Descrição de cultivares locais de feijão-caupi coletados na microrregião Cruzeiro do Sul, Acre, Brasil. Acta Amazonica, v. 45, n. 3, p. 243-254, 2015.

DIAS, F. T. C.; BERTINI, C. H. C. DE M.; FREIRE FILHO, F. R. Genetic effects and potential parents in cowpea. Crop Breeding and Applied Biotechnology, v. 16, n. 4, p. 315-320, 2016.

DOYLE, J. J. T.; DOYLE, J. L. Isolation of plant DNA from fresh tissue. Focus, v. 12, n. 1, p. 13-15, 1990.

EHLERS, J. D.; HALL, A. E. Cowpea (Vigna unguiculata L. Walp.). Field Crops Research, v. 53, n. 1-3, p. 187-207, 1997.

FONSECA, M. A. et al. Ferramentas participativas para diagnóstico da agrobiodiversidade e identificação de agricultores guardiões. Cadernos de Agroecologia, v. 10, n. 3, p. 1-5, 2015.

FREIRE FILHO, F. R. et al. Feijão-Caupi no Brasil: Produção, melhoramento genético, avanços e desafios. 1. ed. Teresina, PI: Embrapa Meio-Norte, 2011.84 p.

FUNDAÇÃO CEARENSE DE METEOROLOGIA E RECURSOS HÍDRICOS - FUNCEME. Postos Pluviométricos. Disponível em: <\&lt;http:// www.funceme.br/index.php/areas/23monitoramento/meteorológico/572-postospluviométricos\#todospelaagua\&gt>. Acesso em: 27 maio. 2017.

GAJERA, H. P. et al. Appraisal of RAPD and ISSR markers for genetic diversity analysis among cowpea (Vigna unguiculata L.) genotypes. Journal of Crop Science and Biotechnology, v. 17, n. 2, p. 79-88, 2014.
GARBUGLIO, D. D. et al. Análise de fatores e regressão bissegmentada em estudos de estratificação ambiental e adaptabilidade em milho. Pesquisa Agropecuária Brasileira, v. 42, n. 2, p. 183-191, 2007.

GOWER, J. C. A general coefficient of similarity and some of its properties. Biometrics, v. 27, n. 4, p. 857-874, 1971

JACCARD, P. Étude comparative de la distribution florale dans une portion des Alpes et des Jura. Bulletin de la Société Vaudoise des Sciences Naturelles, v. 37, n. 142, p. 547-579, 1901.

LOCATELLI, V. DA E. R. et al. Components of production, productivity and efficiency of irrigation of bean-cowpea in the "Cerrado" of Roraima. Revista Brasileira de Engenharia Agrícola e Ambiental, v. 18, n. 6, p. 574-580, 2014.

MANDA, J. et al. The poverty impacts of improved cowpea varieties in Nigeria: A counterfactual analysis. World Development, v. 122, n. 2019, p. 261-271, 2019.

MOJENA, R. Hierarchical grouping methods and stopping rules: an evaluation. The Computer Journal, v. 20, n. 4, p. 359-363, 1977.

NUNES, G. H. S. et al. Implicações da interação genótipos $\mathrm{x}$ ambientes na seleção de clones de eucalipto. Cerne, v. 8, n. 1, p. 49-58, 2002.

OLIVEIRA, J. B.; ARRAES, F. D. D.; VIANA, P. C. Methodology for the spatialisation of a reference evapotranspiration from STRM data. Revista Ciência Agronômica, v. 44, n. 3, p. 445-454, 2013.

OMONDI, E. et al. Molecular markers for genetic diversity studies in African leafy vegetables. Advances in Bioscience and Biotechnology, v. 7, n. 3, p. 188-197, 2016.

PAIVA, J. B. et al. Feijão-caupi: melhoramento genético no Centro de Ciências Agrárias. 1. ed. Fortaleza, CE: Edições UFC, 2014. 261 p.

R CORE TEAM. R: A language and environment for statistical computing. Vienna. R Foundation for Statistical Computing, 2017.

ROHLF, F. J. Adaptive hierarchical clustering schemes. Systematic Biology, v. 19, n. 1, p. 58-82, 1970 .

RUSINAMHODZI, L. et al. Maize-grain legume intercropping is an attractive option for ecological intensification that reduces climatic risk for smallholder farmers in central Mozambique. Field 
Crops Research, v. 136, n. 2012, p. 12-22, 2012.

SANTOS, J. A. DA S. et al. Desempenho agronômico e divergência genética entre genótipos de feijão-caupi cultivados no ecótono Cerrado/ Pantanal. Bragantia, v. 73, n. 4, p. 377-382, 2014 a.

SANTOS, A. DOS et al. Correlations and path analysis of yield components in cowpea. Crop Breeding and Applied Biotechnology, v. 14, n. 2, p. $82-87,2014$ b.

SILVA, F. B.; RAMALHO, M. A. P.; ABREU, Â. F. B. Seleção recorrente fenotípica para florescimento precoce de feijoeiro "Carioca". Pesquisa Agropecuária Brasileira, v. 42, n. 10, p. 1437 1442, 2007.

SILVA, M. B. O. et al. Desempenho agronómico de genótipos de feijão-caupi. Revista de Ciências Agrárias, v. 41, n. 4, p. 201-210, 2018.

SOUSA, J. L. M. et al. Potencial de genótipos de feijão-caupi para o mercado de vagens e grãos verdes. Pesquisa Agropecuária Brasileira, v. 50, n. 5 , p. $392-398,2015$.

STOILOVA, T.; PEREIRA, G. Assessment of the genetic diversity in a germplasm collection of cowpea (Vigna unguiculata (L.) Walp.) using morphological traits. African Journal of Agricultural Research, v. 8, n. 2, p. 208-215, 2013.

TAN, H. et al. A review of molecular makers applied in cowpea (Vigna unguiculata L. Walp.) breeding. Journal of Life Sciences, v. 6, n. 11, p. 1190-1199, 2012.

TANTASAWAT, P. et al. Variety identification and comparative analysis of genetic diversity in yardlong bean (Vigna unguiculata spp. sesquipedalis) using morphological characters, SSR and ISSR analysis. Scientia Horticulturae, v. 124, n. 2, p. 204-216, 2010.

TORRES, F. E. et al. Interação genótipo x ambiente em genótipos de feijão-caupi semiprostrado via modelos mistos. Bragantia, v. 74, n. 3, p. 1-6, 2015.

WENG, Y. et al. Evaluation of Seed Protein Content in USDA Cowpea Germplasm. HortScience, v. 54, n. 5 , p. $814-817,2019$. 